\title{
GOD IMAGES, ETHICAL EFFECTS AND THE RESPONSIBILITY OF SYSTEMATIC THEOLOGY
}

\begin{abstract}
This article registers an important shift that is occurring in contemporary theistic reflection: greater sensitivity to the function of God images, and the consequent ethical impacts. Three texts by Gunton, Johnson and McFague are discussed that exemplify this focus in an emphatic way. From this treatment the implications for Systematic Theology crystallise clearly. The rest of the article entails an exploration of the dynamics of the causal relationship between a specific God image and its corresponding effect. The ramifications for the task and responsibility of Systematic Theology are identified and in conclusion some normative guidelines are suggested.
\end{abstract}

The diversity of images of God people entertain is no neutral given, but is of profound significance for behaviour. The close connection between image of God and the corresponding ethical effect form the focus of this article. For too long this relation has surfaced in theological reflection as an undeniable reality without, to a large extent, the underlying dynamics and implications thereof receiving closer scrutiny. This article is an attempt not only to call attention to the importance of the link, but also to identify the concomitant dynamics. To develop the argument, a crucial shift that took place during the twentieth century will be pointed out briefly. This will be followed by a discussion of the work of three theologians which epitomises the identified phenomenon in an exemplary way. The final and major section of the article will address in a more systematic way the questions raised by this relation. The aim of the article is not to suggest specific God images, or their effects, but to investigate the importance and implications of the link between God image and ethical effect for a specific discipline - Systematic Theology. 


\section{SUBTLE SHIFT IN THEISTIC REFLECTION}

The twentieth century could readily be labelled the century of God: $s /$ he has been charged for being impotent during suffering, $s / h e$ has been declared dead, s/he has received surgically a more dynamic, compassionate face, and in the end s/he has been placed in a loving divine society of mutuality. The fate of God at the hand of creative theologians is a fascinating story in its own right that cannot be recounted in this instance. That the God question has emerged as one of the major concerns of our time (see Tracy 1994) is, however, a major development that should be taken note of. The renewed interest is not a mere retrieval of old teachings, but fresh and penetrating questions are raised. Classical theism has received severe blows to the extent that an alternative profile of God is steadily crystallising. What is of particular interest to me in this article is not the debate on the redefinition of classical attributes mapping the nature of God (e.g. Van den Brink \& Sarot 1995), but another current shift that is taking place rather subtly.

This shift, real but unseen to a large extent, is to be located in the function God is conceptualised to be playing. God is no longer exclusively the active Agent determining the course of history and personal life, but has become increasingly the Model to be emulated - a sort of transcendent point of reference. The embarrassment of theology in the presence of immense historical suffering, the astonishing ability of science and technology to convey a sense of human mastery of life's mysteries, and the depth of realisation of human ethical responsibility may have contributed to this shift in our time. Coupling these with an anti-metaphysical trend in virtually all thinking, the insistence on social relevance for intellectual activity and an awareness of the ethical responsibility of academic work, the shift becomes intelligible. God has not been abandoned in the twentieth century; God's function has been redefined. This shift forms the larger décor for the main argument of this article. This article does not purport to argue for the tenability of the shift, neither for its legitimacy. It is merely registered as an assumption for another but related problematic.

\section{SPECTRUM OF GROWING AWARENESS}

The question could be raised whether the relationship or causal connection between God image and ethical effect is not too readily assumed. The point of this article is not to deny other determinants of behaviour, but to stress this as having been neglected for too long. Neither is it assumed that the relationship is simplistic or direct. At least some correspondence between the content of the image and the quality of effect is posited. As to factual evidence, reference can be made to some empirical research done by Piazza and Glock (1979) in this regard. They proved conclusively that behind the simple acknowledgment of 
belief in God lurks substantial different images of God. Their research identified four images of God: One image perceives God as active at both personal and social levels; a remote image does not conceive God as having a personal or social influence; a third and personalist image views God as guiding daily personal life but not determining social life, and a final and alienating image pictures God as personally distant, but still regulating the social order. This classification of God images reflects, according to the research, genuine differences between the types in their acceptance of traditional religious beliefs and practices, political disposition and attitudes to specific social issues such as women's role, racial policies and personal helpfulness. ${ }^{1}$ They conclude their research by stating (Piazza \& Glock 1979:91):

In attempting to understand the relationship between religious belief and social life, the type of God in which people believe may be one of the most important things to study.

In my opinion this importance cannot be stressed enough. For too long the effects of God images have been neglected and the images themselves regarded as innocent, accurate and final representations of God. The examples, briefly mentioned in the previous section, indicate the breadth of the influence of God images - from the individual to the social structural level. At stake in this problematic is the continued relevance and vitality of the Christian faith to the dilemmas of our time.

A number of theologians working in disciplines other than Systematic Theology have called attention to the relationship between God image and effect and its importance. Referring briefly to this work is an attempt at emphasising the interdisciplinary nature of the task of Systematic Theology.

The imitatio Dei is an explicit Biblical motif, both in the Old (e.g. Birch 1995) and the New Testament (e.g. Schneider 1989). Counsellors (e.g. Van Jaarsveld \& Janse van Rensburg 2002, and Shaap-Jonkers 2004) call attention to the importance of God images and the effect on the health and spiritual growth of the persons consulting them. The presence of dysfunctional images of God may be one of the major causes preventing and inhibiting personal wellbeing.

The subtle interrelationship between religious and political discourse on God and the state has been well recorded. Nicholls (1981), for example, indicates how concepts and images of God have been closely associated with images and concepts of political authority, which in turn have been related to institutional developments. For example, from the Renaissance to the seventeenth cen-

1 See this article for the sometimes unexpected and surprising detail, e.g. the personalist model encourages traditional attitudes concerning religious beliefs and practices, but do not tend to be conservative in political and social matters. 
tury an analogy developed between divine and political authority of unlimited power combined with benevolence (Nicholls 1981:201f.). Theologians living in democracies such as the USA are usually assailant to monarchical images of God and argue in favour of more democratic ones. He points out the complex nature of the relationship: The institutions in which people live influence their experience; this, in turn, affects the formation of concepts. On the other hand, concepts of God affect the development of religious and political institutions. Glock (1972:5f.) points out that sanctions - reward for conforming behaviour and punishment for deviance - are part of all imagery of God. This amounts to "the possibility of a political critique of the images of divine authority and a theological critique of the state" (Nicholls 1981:215). Even now that the main organisational axis of political society is no longer religious and religions have been marginalised and relegated to the private sphere, the God question is not politically neutral. Says Durand (1972:74): "Even though faith is not an ideology, there is no faith without ideology, any more than there is a God question without political implications."

\section{GOD IMAGES AND ETHICAL EFFECTS: THREE REPRESENTATIVE CASES}

It may be productive for the main focus of the article to concentrate on theologians whose work exemplifies the connection of God images and ethical effects. In the account of their work some of the dynamics will be highlighted that may contribute to a more systematic treatment of the problem. Colin $E$. Gunton, Elizabeth A. Johnson and Sallie McFague have been selected. Not only are they major thinkers of our time, ${ }^{2}$ but also their theological labour instantiates the relationship in an astonishing way. A major text by each one will be discussed. ${ }^{3}$ Despite differences, the argumentation employed by the three follows a surprisingly similar underlying structure: It is motivated by a perception of a crisis; it critiques traditional theism for its complicity; it displays a clear understanding of the nature and task of theology; it offers a creative reconstruction of the image of God as assumed corrective to the crisis, and it anticipates an alternative ethic. The treatment of the texts will be structured accordingly.

2 Sadly, Gunton passed away in 2003; the other thinkers are still active and producing exciting work.

3 All page references in the texts will be to these books. These works form, arguably, some of their most substantial reflection, although they are not the most recent publications. 


\subsection{Colin C. Gunton}

Systematic Theology

The fragmentation of modern Western culture and its decline into subjectivism and relativism is for Gunton, in his work The one, the three and the many, of particular concern and constitutes the crisis of modernity $(1993: 2,106)$. His work offers a theological account of the shape and failure of modernity. The figures of Heraclitus and Parmenides represent the problem of the one and the many, or that of unity and plurality and of the individual and society. Gunton discerns a trend towards monism in modernity, the triumph of the Parmenidean. The emergence of modernity has resulted in deficient notions and practices with regard to relationality, particularity, temporality and truth (1993:123). The relentless pressure for homogeneity is the real threat of modernity (1993:39). The rights of the many are subverted by new and demonic versions of the one: Either the many become an aggregate of one, or the many become homogenised (1993:33). An inadequate conception of relationality and the abolition of particularity are responsible for modernity's failure to hold in tension the concerns of the one and the many, of the unity and of diversity, and of social cohesion and individual independence. The failure to integrate the three central dimensions of the human being, which are important for the health of a culture - truth (science), goodness (ethics) and beauty (art) - conveys "modern fragmentation in a nutshell" (1993:116). Gunton views the relation between modernity and post-modernity as continuous; it is a naïve assumption that something truly new is happening in reaction to modernism (1993:5). Both are different versions of one modern procrustean ideology: the Parmenidean trend to homogeneity. Modernism excludes the other, whilst postmodernism seeks to render it irrelevant (1993:227).

The predicament of modernity is directly related to the displacement of the Christian God, says Gunton (1993:38): "My contention is that the distinctive failures of our era derive from its failure of due relatedness to God." The healing of the fragmentation is not to be achieved by either the rehabilitation of traditional theism or the opting for a theology of immanence. Traditional theism shares the blame for the emergence of modernity; the prime culprit is Christian theology's tendency towards a monolithic concept of God. Conceiving of God as single, simple and unchanging contributes to the rebellion of the many against the repressive one.

In this situation Christian theology has the responsibility of contributing to the healing of modern fragmentation. Gunton does this by addressing the crisis of modernity at the level of ontology (1993:219) and rebuilding the foundation on trinitarian transcendentals (1993:155). Ultimately, his concern is

to develop a trinitarian analogy of being (and becoming): a conception of the structures of the created world in the light of the dynamic of the being of the triune creator and redeemer (1993:141). 
Trinity and creation become the foci of his theological project. The notion of open transcendental is central in his argument; it is a notion basic to the human thinking process which enables the exploration of the universal marks of being (1993:142). A theology of transcendentality is rooted in the doctrine of the trinity.

Gunton responds to the perceived crisis with a specific understanding of God: A trinitarian God functions as an idea that generates transcendentals. The underlying assumption is that all of creation reflects the being of God, the source of all meaning and truth (1993:145). To construe an alternative to the deficient traditional theism that contributed to the rise of modernity, Gunton starts with the notion of divine economy as God's action in and to the world in time and space, which is diversified within fundamental unity. The concept perichoresis that emerges from this movement preserves both the one and the many in dynamic interrelations: "God is what he is by virtue of the dynamic relatedness of Father, Son, and Spirit" (1993:165). This notion of relatedness safeguards particularity as persons are constituting each other, making each other what they are (1993:169). At the heart of the being of God is thus to be found particularity, by virtue of the three persons' relationality to one another (1993:194).

The next step in Gunton's argument is crucial. He extrapolates from this conception of the trinity a specific understanding of the creation. He finds the bridge in the creator-creation link: All being is marked by its relatedness to the creator $(1993: 124,166,167)$. A specifically construed trinity leads to a concomitant ontology - an ontology of communion which connects being and relation (1993:214). Three open transcendentals result from this approach to the trinity: perichoresis, substantiality and relationality. The universe is perichoretic, meaning that everything in the universe is what it is by virtue of its relatedness to everything else (1993:172). Such an ontology honours uniqueness, distinctiveness and diversity within unity. Gunton's project is most ambitious. When stating that theology is a practical discipline that must be judged by its fruit, he intends to heal the fragmentation of the human cultural enterprise (1993:7 \& 151f.). He believes it has implication for the alienation of truth, goodness, beauty, individual and society.

\subsection{Elizabeth A. Johnson}

In her carefully constructed and beautifully written work - She who is Johnson addresses sexism, patriarchy and androcentrism, and their destructive and dehumanising social and psychological effect on women. The suffering, exclusion and marginalisation of women are the primary concern of her creative theological work. Theologically the book is a forceful argumentative case for the legitimacy of women's reality to represent God and its resultant liberative impact. 
That religious language and symbols function in a powerful way is a central assumption pervading her work. Language does not only express a world, but also shapes and creates it. Likewise symbols shape an orientation to life, mould identity and direct praxis. Consequently, speech and symbolisation about God, as the ultimate point of reference for understanding experience, life and the world, is of utmost importance as they have the potential to sustain or critique structures, values and ways of doing (1992:47 \& 36). The deficiency of traditional theism is to be found in its complicity in the oppression of women. Johnson is particularly concerned about the effect of traditional theism. The God of traditional theism is a subtle tool of conditioning, and legitimates and reinforces the suffering of woman (1992:36, 38).

To establish emancipatory speech about the mystery of God, she develops an intricate and multi-layered argument. In order to deconstruct the prevalent patriarchal speech she stresses that the mystery of God is always mediated through historical discourse that renders all such speech contingent (1992:6). Secondly, the referent of the word "God" is incomprehensible and no speech can exhaust the mystery of God (1992:10). A third emphasis validates a multiplicity of names for God by virtue of the fact that both man and woman are the image of God (1992:55). Female imagery as representations can be legitimated by the equal status of women as the image of God. By retrieving in the fourth place the neglected Biblical trajectory of Wisdom as the female personification of God (1992:91), she establishes a foundation to speak about God from a non-patriarchal perspective. Finally, in light of classical theology, Johnson states the negating power of all analogous talk about God (1992:117). These arguments serve to erode the stability of patriarchal speech and clear the way for her project to establish an image of God with a different content "to heal imaginations and liberate people" (1992:43).

To reconstruct the image of God Johnson follows quite an ingenious approach by starting inductively with the Holy Spirit to establish the character of God in a trinitarian fashion. This amounts to a theology of the triune God "from below" (1992:123). From the optic of wisdom and maternal imagery she looks successively at the Spirit-Sophia, Jesus-Sophia and Mother-Sophia. From each she gleans new perspectives on an alternative image of God. Central in her construal, however, is a reinterpretation of traditional trinitarian doctrine as such and she attempts to replace the existing male and hierarchical imagery with a communio approach. By modelling the trinity on relations of friendship, three important insights emerge: mutual relations, radical equality and community in diversity (1992:215ff.). At the heart of the universe the trinity provides a symbolic picture of totally shared life and forms the ultimate reference point for the values of a community (1992:223). The ambitious nature of Johnson's project surfaces in her final step to employ ontological categories to speak about God: The very essence of the holy mystery is "to be"; "the notion of God as being 
signifies ultimate reality as pure aliveness in relation" (1992:240). In conclusion Johnson names God as SHE WHO IS - "the ontological symbol of absolute, relational liveliness that energizes the world" (1992:243). God conceptualised as such requires a revision of classical theism, and the notions of impassibility and omnipotence. The divine capacity for suffering signals God's involvement in and solidarity with the world as an act of love freely overflowing in compassion (1992:265). Compassionate love appears not as an imperfection, but as the highest excellence. Likewise a re-symbolisation of power is required - power not as domination or control, but as empowerment through love.

An alternative image of God crystallises from Johnson's work. She is acutely conscious of the fact that a changing ethical ideal has far-reaching ramifications for speech about God (1992:69). And this is exactly what she has in mind as ultimate goal: the transformation into a new community (1992:31) characterised by relations of mutuality and reciprocity (1992:6). It is not about reverse sexism or sameness, but about a new model of relationship; one that is inclusive and celebratory of difference. By deconstructing the patriarchal image of God and reconstructing an alternative in female categories she has made an impressive argument for the flourishing of women.

\subsection{Sallie McFague}

The question of power as dominion and control, and the knowledge that human beings have the power to destroy life and death form the focus of McFague's theological concern in her work Models of God. Considering human dominion and ruthlessness in a nuclear age the issue is whether life or death will prevail. This ecological crisis lies at the heart of her project. The pervasiveness of triumphalist approaches to life and absolute hierarchical dualisms necessitates reflection towards a new sensibility, especially concerning the non-human life.

How the relationship between God and the world has been imaged and expressed in language in traditional theism contributed to the predicament (1987:20). The monarchical model, featuring God as the lord, the king and the patriarch and the world as his realm and conveying the impression of power as dominion, has been the central characteristic of the Western view of God (1987:16). In light of the following three flaws this image needs drastic and urgent revision (1987:65): It pictures God as being distant from the world, as relating only to the human world and as controlling the world through domination and benevolence (1987:65). The very danger of this model is its psychological power: It not only encourages hierarchical, dualistic thinking of the kind that fuels oppression, but it also encourages attitudes of either militarism and destruction or passivity and escape $(1987: 64,67,69)$. Our time lacks an imaginative construal of the God-world relationship along a different set of categories engendering an alternative ethic. 
McFague is not only ready to deconstruct an outdated image, but is also prepared to propose a reconstruction on the basis of a postmodern metaphorical theology. The crux of her project is to address the question of appropriate metaphors and models that address the relationship between God and the world for our time (1987:29). To replace the reigning monarchical model she pursues an ecological perspective that stresses relationship, interdependence and mutuality to convey the relationship between God and the world $(1987: 8,60)$.

To effect an ethic relative to the depth of the present crisis, McFague reimages God as the body of the world and as Mother, Lover and Friend. A pantheistic approach, denying the reduction of everything to God, conveys the universal immanence of the transcendent God (1987:72, 185). The three metaphors - Mother, Lover and Friend - arise from the most basic level of physical existence; counter an interventionist understanding of God and the world, and underline God's intrinsic relationship with all else that exists $(1987: 81,83)$. They are immanent models projecting a different view of power, not that of control, but of love (1987:85). Referring to God as Mother can strengthen an awareness of the depth of God's impartial love (agape) for all creation. God is intimately linked to the beginning and the nurturing of all life. The need for stressing the intrinsic value of the world in our time is addressed by the metaphor of God as Lover. Love as eros, a passionate desire to be united with the other and the valuing of the beauty and goodness of the other is embedded in the Lover metaphor. It allows for the notion of passion of part of God's nature and it underscores the need God has for the world (1987:129, 134). The friendship model expresses the most inclusive and free nature of love (philia). This unmistakably raises the joy of interrelationship. The three metaphors, each embodying a different dimension of God's love for the world, together amount to McFague's reconstruction of the trinity. She denies an explicit trinitarian approach, but leaves the possibility open that the Mother, Lover and Friend metaphors could convey the creative, salvific and sustaining quality of God's love (1987:181ff.).

McFague is most explicit about the primary thrust and intention of her project: An alternative ethic is required by the gravity of the ecological crisis. A new way to visualise the relationship of God to the world will enter the consciousness to engender a new way of being in the world. She believes an ethic of justice, healing and companionship will accompany the metaphors of Mother, Lover and Friend. Once people see differently, they will act differently. Finally, her project is about human responsibility for the non-human world. New metaphors can enhance this. 


\subsection{Concluding comments}

A number of observations, calling attention to salient features of the work of Gunton, Johnson and McFague, may be justified. This can also lead to a more systematic treatment of the relationship between God image and ethic, and the eventual implications for Systematic Theology.

- The departure from theology as naïve transmission of a static and neutral content is decisive. Theology is not only deeply committed to be socially relevant, but also as interpretative activity a thoroughly creative and constructive enterprise.

- Imaging and conceptualisation of God is not some simplistic representation and distillation of Biblical proof texts, but the result of careful rhetorical endeavour.

- Despite all their differences the three theologians have one insight in common: Whether the word "God" is understood as concept, symbol, image or metaphor, what matters is that the constructed content does have an impact on people employing it.

- All three theologians conspicuously neglect to account explicitly and in detail for the nature of the dynamics of the causal relationship between a specific God image and the corresponding effect. This calls for further reflection and research.

\section{SYSTEMATIC REFLECTION}

\subsection{Note on terminology}

The meaning of the word image has not yet been accounted for. For the purpose of this article image refers to the totality of a person's understanding of God. This may be subconsciously operative and/or the result of a deliberate reflective endeavour. As a composite category it may contain metaphorical and conceptual dimensions. Usually an image has a coherent nature with certain dominant features, which identifies it as unique.

\subsection{Accounting for the relation}

Why is there an intrinsic relation between the symbol, the metaphor or image of God and the consequent effect on those having internalised it? Notwithstanding the lack of explicit treatment of the question, the few suggestions discussed by the three theologians in their work are helpful in this regard. At least 
three approaches surface cursorily: an anthropological, a phenomenological and a theological explanation.

The human being needs transcendent points of reference to orientate and integrate life. The image of God fulfils this basic need. This approach originates from ancient Greek philosophy for its resources and examples.

Human language and symbols are potent and active, and effect human consciousness to determine behavioural patterns. The linguistic turn in our time and the discovery of the key role symbols play in cultures give an impetus to this approach. It highlights the fundamental distinction between the reality of God and the human symbolic and linguistic representation of God. The human being has only a mediated access to God. Simultaneously, the performative dimension of language is emphasised.

Theologically a number of possibilities are open for consideration. The inextricable link between creator and creature results in some sort of ontological and ethical analogy. This is then usually linked with the traditional motif of the creation in the image of God. The imago Dei and imitatio Dei go hand in hand. The incarnation reinforces this connection further. The net theological result is one of a sacramental universe in which we live. The human being cannot escape from his/her creator and is called to reflect or echo the being and character of this very God.

The three approaches are probably complementary and the connection is to be accounted for by an intricate configuration of ontology, history, language and consciousness.

\subsection{Implications for Systematic Theology}

It is my basic conviction that the relation between God image and ethical effect is of such importance that it should be addressed as the central focus of an academic discipline, and this I believe is the responsibility of Systematic Theology.

\subsubsection{The nature of the systematic activity}

The question of the nature of Systematic Theology is complex and far-reaching, and it is obviously not within the scope of this article to deal with this exhaustively. One - usually neglected - aspect of the character of Systematic Theology needs some attention. Most of the time discussion centres on sources and methods, with attention to Scripture, tradition, reason and now more often experience. Finally, the one doing the theology escapes scrutiny. This human aspect of the activity concerns me. 
The result of the activity of Systematic Theology — the printed text - is the outcome of creative, imaginative, ideological and cognitive human endeavour. If the product is the configuration of sources used, the method employed and the manifestation of this human dimension, what are the implications for determining the nature of the systematic activity? Two categories may be useful to capture what is at stake here: construction and representation. Systematic Theology, metaphorically speaking, erects an edifice. The various houses into which the reader is invited differ and the quality of the accommodation varies. Or to change figurative language: The systematician, an artist drawing a profile, highlights certain features of the identity of the Christian face and, inevitably, undervalues others. Representation, a notion encountered often in postmodern discourse, stresses the distance and space between human signification and the signified. This could be used to gain insight into the nature of Systematic Theology. Despite the vast differences among progressive and more conservative voices there is a common aim to attend to the Bible, the past and the present in divergent configurations of approach in order to speak a meaningful word for our time. This "attend to" is nothing but an effort to represent. Postmodernism's contribution is to make us aware that representation is never innocent. This is the point in this instance: the farewell to naiveté concerning the nature of Systematic Theology. There is no direct line between the Bible, the tradition, the confessions, the context and the final text of Systematic Theology. The road from these sources (or norms) must pass through the tunnel of the theologian's own creative, ideological, and imaginative mind. The theologian must continuously make choices, sometimes consciously, but most of the time unreflectively, about how to proceed. This character of the activity of Systematic Theology unmasks the myth of stable representation, and discloses its impossibility. Systematic Theology cannot distil or systematise revelation or the message of the Bible propositionally; it always creates a thoroughly personal interpretation on the basis of these normative sources.

What the systematic theologian presents as his/her concept, image or symbol of God is thoroughly his/her own representation and construction. A short example may be helpful. For argument sake, a number of scholars are requested to articulate the identity of the Christian God. How will the very act of fulfilling this task proceed cognitively? It is intellectually impossible, provided there is no option of parochialism, to ignore fundamental questions raised in this century during the completion of the task. How does the theologian incorporate categories and perspectives such as the future, power, suffering, language, transcendence and immanence, relationality, justice, change, agency and causality in the picture? First, no juggling of all in a harmonious balance could be achieved; some preference will surface. Secondly, more fundamental decisions will have to be taken. The result will be highly divergent and intensely personal images of the same God. My specific interest in this article is the underlying dynamics. 


\subsubsection{The responsibility of Systematic Theology}

Systematic Theology

Why the emphasis on this specific aspect of the nature of Systematic Theology? The reason is obvious. It is an attempt at promoting deepened consciousness of the character of Systematic Theology so that theologians accept greater responsibility for the constructs of their God images, and do this more attentively, especially in light of the impact these may have on those who internalise them. It comes down to the simple question: Why like this, and not like that? And, if this is accepted, to what effect?

The recent renaissance of the God question and trinitarian thinking may contain the potential for a thoroughly theological treatment of the scope of Systematic Theology which does not relegate the treatment of God to one chapter and discuss the traditional loci or doctrines in isolation from God. The project of Gunton to view creation, anthropology and ecclesiology in trinitarian light exemplifies what could develop from this line of thinking. If this could be the way for Systematic Theology in some circles, the question of the dominant image of God becomes even more urgent.

My conviction is that Systematic Theology should view the careful and attentive construction of a God image as its central task and responsibility. Once a clear profile of this has emerged, the traditional questions of creation, providence, the human being, salvation, the church, sacraments, and eschatology could be dealt with in light of this representation. Other fundamental questions are to be addressed in relation to the specific understanding of God.

My suggestion promotes a greater attention to the dynamics of the actual theological activity and the constituting factors involved. This is a plea for considering the quality of our language, the diversity of options available and the relentless presence of ethics.

If a sensibility for the essential connection between God image and ethical effects accompanies this central task of Systematic Theology, the alienation from other theological disciplines such as Liturgics, Spirituality, and Pastoral Counselling could be overcome. If God construction is guided by a criteriology of effect, the relevance of Systematic Theology becomes immeasurable for identity formation. Simultaneously, such a sensibility would enhance the apologetic function of Systematic Theology. It opens the possibility of an interface between academy, church and society. Conceptualised in this way, Systematic Theology accepts consciously and deliberately responsibility for the wellbeing of individuals, church and even community. 


\subsection{Dilemmas}

\subsubsection{Scope and freedom of construction}

An equally pressing question is to what extent are theologians free in their creativity and their imaginative constructions. The actual dynamics are not particularly difficult to depict: A certain element of functionalism and pragmatism colours the projects described. All three theologians believe that an alternative approach to the category relationship could make a world of difference and, in order to achieve that, a reconstructed God image could be helpful. All three were, however, constrained by some element that they believe embodies the integrity of the Christian God: For Gunton it is the trinitarian economy; for Johnson the Biblical notion of Wisdom and the trinity; and for McFague love. This is an important insight. Images of God to be Christian images are not entirely free. The Christian faith leaves an intriguing space for interpretation, but there are limits to redefinition before its integrity is violated.

The word of caution about integrity and limitations is not an apology for the stability and permanence of our God images. The very nature of God as God, and the very nature of our theological activity erode the finality of our images and make reconstruction imperative. The Christian Scripture contains a definite growth in understanding God. At the end of the twentieth century the central question to answer is whether a fundamentally new picture of God is not in the process of emerging and being crystallised. To what extent can a monistic, impassible, immutable, sovereign image of God survive? Should work done on God and eschatology, God and suffering or vulnerability, God and language, God and change, God and relationality, God and justice, God's immanence in the world - to name a few major developments - be relegated to the status of new perspectives, but never be taken seriously to transform our dominant images in the textbooks prescribed in the seminaries of mainline churches?

\subsubsection{Status of the God image}

Stating the importance of God images for the life of those who live by them, and for the entire content of the Christian faith, is only the beginning of the investigation of the problematic. A number of questions come inevitably to the fore. What is at stake in this instance is the function of the theologian's constructions, or concepts or metaphors of God. As seen in the work of the three theologians selected, the understanding of the nature of God is not only about saying something about God, but about doing something with the construction. In their respective cases it was to address the problems raised by modernity, sexism and ecology. God, as represented by their alternative constructions, 
has to solve the crisis. This is exactly the question: To what extent could God images address fundamental existential, social and cultural problems? As the primary religious symbol, the ultimate point of reference, the potential cannot be underestimated. To address perceived crises in this way is to penetrate the deepest layer of possible explanation. This may even signal a very fruitful method of doing theology. Some proviso is, however, needed. A careful reading of the three theologians (especially Johnson and McFague) expects the hoped for change as a result of transformed behaviour. In so far as human behaviour can address the problem and be effected by transcendent images, the constructions of God by theologians may be helpful. To insist on the crucial importance of God images is not a way to subsume all possibilities by it, but it opens interesting avenues for doing contextual theology.

\subsubsection{Truth of the God image}

Pleading for the recognition of the power of God images, and promoting the active construction of God images is no effort to succumb to an exclusive pragmatist approach to truth. The impression may be easily left that the employment of the word construction either denies or ignores the reality of the referent. This is not the intention of this article at all. All God images must ultimately account for the truth of their content; truth at least in the sense of correspondence with the Bible, and truth as coherence in the sense of interrelation of all its ramifications. This, however, does not deny the pragmatic element of truth.

\subsection{The dynamics of construction: Some perspectives}

To call attention to the effect of God images is simultaneously to offer a small apology for their construction, and to call for an antenna to the dilemmas of our time. How to proceed may be the hardest of all. Raising consciousness of the impact of God images is one thing; getting engaged in active construction is quite another. I suggest that the following be considered for meaningful systematic activity.

- Without recognition of the distance between our images and the reality little progress can be made. For too long an ultra-realist position has been entertained, assigning final and fixed status to linguistic approximations of the nature of God. Questioning these articulations often implies for some the critiquing of God as such. As long as the tentative nature of theological constructions is not viewed for what they are, the discourse will remain closed and inhibited. An appreciation of the linguistic nature of the systematising activity, and of the debates on realism, critical realism and constructivism may contribute to a meaningful naming of God for our time. 
- An awareness of the internal diversity in Scripture is imperative for imagining God resonant with the richness of revelation. Many of the attempts at reconstruction have ignored the voices of Scripture and have scrutinised it merely to find proof texts for some profile believed to be God. Fortunately, an increasing number of Biblical scholars are voicing the presence of this very diversity (e.g. Das \& Matera 2002). In this regard the work of Brueggemann needs to be mentioned. Unwilling to accept a simplistic uniform picture of God, he points out the unresolved tensions and unsettled ambiguities in the identity, person and character of God in the Old Testament (e.g. 1995 \& 1997). The potential of his work to inform a relevant Systematic Theology can scarcely be overstated. Whether the foundational document of the Christian faith contains an underlying coherent picture of God amidst its diversity is a crucial question to be addressed (see Patrick 1981:46-60.). Accompanying this question is whether the construction of a stable and comprehensive image is possible at all. Are we not doomed (or privileged) to a theology of God in fragments (see Pohier 1986 \& Tracy 2000)?

- Closely related to the previous suggestion is an insistence on the inescapable hermeneutical nature of all encounter with the Bible. The interpretational advances in the bibliological disciplines have not yet found fertile application in Systematic Theology, and remain one of the tragic features of the academic study of theology. The surplus of meaning of texts, unlocked by methodologically informed reading strategies from the perspectives of the Other (e.g. the poor, women), must be considered by Systematic Theology. That perspective and method could elicit variant pictures of God is an exciting reality for any construction of a relevant theology for our time. No theology of God can be developed without an interaction with the hermeneutical developments of the past century.

- Acceptance and internalisation by the believing community cannot be ignored when effects and impacts are the focus. It is futile to propose images that have no intended audience and are not received by believers. The relation between the ecclesial public and the academic discipline becomes acute when the construction of God images is considered. An element of tension is obvious; people must be challenged; this must be clearly distinguished from antagonising them which is often the case. The rhetorical dimension of Systematic Theology, which is most often ignored, requires that discourse be persuasive to its intended audience and meaningful. Conscious employment of argumentative strategies marks quality theology. However, more is at stake than a mere acceptance; the final criterion will be whether images allow people to worship God (LaCugna 1993:108). The worshipping community must ever be present in the mind of the systematician. 
- Critics of traditional theism are quick to point out the deficient categories utilised for speaking about God. If static and substantialist thinking from the Greek world has contributed to the present discontent, what is the alternative route to travel? I am convinced that post-modernity with its preference for irony, ambiguity, paradox and dialectic may be a welcome partner in the search for adequate categories to image God. This may prove to be a more fitting way to represent the elusiveness and freedom of God. Our images must convey a sense of the mystery of God, and our inability to cage God to the confines of simplistic reflection.

- A certain circularity manifests itself in the process of designing images of God. Not only is the movement from God image to ethical effect, but also from ethic to the image of God. Two concerns are raised and both can be the object of intellectual inquiry: the importance of God images in light of their consequent impact and the determining influence of interests and ethical positions steering the creative process. The circularity acquires a dialectical tension. Ethics and Systematic Theology are inextricably interwoven and the professional systematic theologian must account for the, sometimes unexamined, ethical assumptions influencing reconstructive endeavours and assume responsibility for the impacts of his/her symbolic worlds.

- If the previous suggestions are accepted, the contextual quality of all systematic work becomes an undeniable challenge. Construction is contingent, local and historical, addressing a concrete exigency. This approach to Systematic Theology bids farewell to abstract and universalising thinking and requires an account of the perceived horizon the theologian is addressing. Systematic Theology must be informed by cultural studies, politics, economics, psychology and sociology, to mention a few, to understand the crisis of our time. How the theologian discerns this is decisive for the entire imaging process.

\section{CONCLUSION}

The reality of divergent God images is pervasively present and the effects of these understandings have been too widely recorded to be neglected. It is my conviction that Systematic Theology must address the implication of this relation in a fundamental and constructive way. This will require a re-orientation of the responsibility, nature and task of Systematic Theology. Numerous questions remain to be answered, but this approach holds the promise for a meaningful engagement between Systematic Theology and the challenges of individual, ecclesial and social wellbeing. 


\section{BIBLIOGRAPHY}

BIRCH, B.C.

1995. Moral agency, community, and the character of God in the Hebrew Bible. Semeia 66:23-41.

Brueggemann, W.

1995. 'In the image of God' ... pluralism. Modern Theology 11:455-469.

1997. Theology of the Old Testament: Testimony, dispute, advocacy. Minneapolis: Fortress.

DAs, A.A. \& MATERA, F.J (Eds.)

2002. The forgotten God: Perspectives in Biblical Theology. Louisville: Westminster John Knox.

Durand, A.

1972. Political implications of the God question. In: J.B. Metz (ed.), New questions on God (New York: Herder \& Herder), pp. 67-74.

GLock, C.Y.

1972. Images of "God", images of man, and the organization of social life. Journal for the Scientific Study of Religion 11:1-15.

Gunton, C.E.

1993. The one, the three and the many: God, creation and the culture of modernity. Cambridge: Cambridge University Press.

JoHnsON, E.A.

1992. She who is: The mystery of God in feminist theological discourse. New York: Crossroads.

LACUGNA, C.M.

1993. God in communion with us: The trinity. In: Idem (ed.), Freeing theology: The essentials of theology in feminist perspective (San Francisco: Harper), pp. 83-114.

McFague, S.

1987. Models of God: Theology for an ecological nuclear age. London: SCM.

NiCHOLLS, D.

1981. Images of God and the state: Political analogy and religious discourse. Theological Studies 42:195-215.

PATRICK, D.

1981. The rendering of God in the Old Testament. Philadelphia: Fortress.

PiAZZA, T. \& GLOCK, C.Y.

1979. Images of God and their social meanings. In: R. Wuthnow (ed.), The religious dimension: New directions in quantitative research (New York: Academic Press), pp. 69-91. 
POHIER, J.

1986. God in fragmenten. Hilversum: Gooi en Sticht.

SCHAAP-JONKER, $\mathrm{H}$.

2004. The varieties of God: Een overzicht van onderzoek naar godsbeelden. Nederlands Theologisch Tijdschrift 58:124-141.

SCHNEIDER, G.

1989. Imitatio Dei als Motiv der "Ethik Jesus". In: H Merklein (Hrsg.), Neues Testament und Ethik (Freiburg: Herder), pp. 71-83.

TRACY, D.

1994. The return of God in contemporary theology. In: C. Geffré \& W. Jeanrond (eds.), Why theology? (London: SCM), pp. 37-46.

2000. Form and fragment: The recovery of the hidden and the incomprehensible God. CTI Reflections 3:62-88.

Van den Brink, G. \& Sarot, M. (Reds.)

1995. Hoe is uw naam? Opstellen over de eigenschappen van God. Kampen: Kok.

Van JaArsveld, F.J. \& Janse van Rensburg, J. 2002. Godskonsepte tydens pastorale gesprekvoering. Acta Theologica 22:179-197.

Keywords

Systematic Theology

God images

Ethics

Colin E. Gunton

Elizabeth A. Johnson

Sallie McFague
Trefwoorde

Sistematiese Teologie

Godsbeelde

Etiek

Colin E. Gunton

Elizabeth A. Johnson

Sallie McFague 